\title{
Influence of Rainfall Pattern in the Seasonal Variation of Fish Abundance in a Tropical Estuary with Restricted Marine Communication
}

\author{
Manuel Castillo-Rivera \\ Departamento de Biología, Universidad Autónoma Metropolitana, Unidad Iztapalapa, México DF, México \\ Email: crma@xanum.uam.mx
}

Received January 13, 2013; revised February 14, 2013; accepted February 21, 2013

\begin{abstract}
Pueblo Viejo Lagoon is an estuary with restricted communication with the sea, so the freshwater influence tends to be more important. Therefore, the study focused on testing the hypothesis that the seasonal changes in species abundance would be mainly related to the local rainfall pattern. Monthly samplings were carried out over a one-year, using a seine net. A total of 9108 individuals were caught, corresponding to 66 species of fish, most of them with marine origin. Canonical correspondence analysis revealed that the rainfall-salinity gradient was revealed to be the most important driving force in the seasonal variation of fish composition. In this way, it was observed that seasonal fluctuations in total fish number were linked to preceding fluctuations (one month) in local rainfall. Similar pattern was exhibited by the abundance of Anchoa mitchilli (the most abundant species), Oreochromis mossambicus and Ariopsis felis, and this delayed effect was significant (cross-correlation analyses). In addition, the rainfall showed a direct influence (significant positive correlations) on abundance of $D$. auratus and M. martinica. The association between fish number and the rainfall regime seems to be related to lagoon productivity and the trophic responses of these species. By contrast, Brevoortia gunteri and Menidia beryllina showed an inverse correlation with rainfall. Other environmental variables (also influenced by rainfall regime) showed a significant relationship with A. hepsetus (salinity), B. chrysoura (depth) and $M$. curema (turbidity). Thus, at least 12 species showed some relationship with local rainfall, which accounted for $81.27 \%$ of the total number of fish collected. Although it is difficult to separate the relative importance of physiological tolerances and biological functions such as trophic responses, the results suggest that rainfall is a primary factor governing seasonal variation in fish species abundance of Pueblo Viejo lagoon.
\end{abstract}

Keywords: Constrained Ordination; Delayed Effect; Salinity; Depth; Turbidity

\section{Introduction}

One of the primary goals of fish community ecology is to analyze the seasonal variations in the relative abundance of species. In this sense, the role of seasonal variability in environmental factors in structuring the fish communities in estuaries has been the focus of many studies. Many of these studies have demonstrated changes in species composition and abundance, which may be influenced by constant fluctuations in environmental factors, such as salinity, temperature, and turbidity [1,2]. In particular, salinity is one of the more important environmental factors structuring the fish estuarine communities and in many systems, has a significant effect on fish distribution [3-6]. However, the levels and ranges of this factor can be largely determined by the seasonal rainfall patterns, and there is little information about the direct influence of local rainfall patterns (and related freshwater inputs) on species distribution and abundance.

The lagoon of Pueblo Viejo, in the northern part of the Mexican state of Veracruz (western Gulf of Mexico), is an estuary with restricted communication with the ocean, so the freshwater influence tends to be more important. This system is an important area in terms of regional biogeographic variability and fish diversity since it is located near the boundary between two major zoogeographic regions, the tropical Western Atlantic Region (Caribbean Province) and the temperate North American Atlantic Region (Carolinian Province) [7]. Also, the lagoon has been designated a priority marine conservation area because of its high biodiversity [8].

In this way, the present study focused on testing the hypothesis that the seasonal changes in fish structure and relative abundance of species would be mainly related to the local rainfall pattern. The main objective was, there- 
fore: describe the main patterns of seasonal variability in fish abundance, in terms of the influence of environmental variables with major seasonal incidence, with particular emphasis on the rainfall regime.

\section{Material and Methods}

\subsection{Study Area}

The lagoon of Pueblo Viejo is located in the northern extreme of Veracruz State, Mexico $\left(22^{\circ} 05^{\prime}-22^{\circ} 13^{\prime} \mathrm{N}\right.$, $\left.97^{\circ} 50^{\prime}-98^{\circ} 00^{\prime} \mathrm{W}\right)$. It is a shallow estuary with a mean depth of $1.31 \mathrm{~m}$ and an area of $88.7 \mathrm{~km}^{2}$. In its northern part, Pueblo Viejo Lagoon connects to the Pánuco River (the fourth largest river in Mexico by volume of runoff), approximately $10 \mathrm{~km}$ from where the river empties into the Gulf of Mexico, and can thus be considered an estuary with restricted communication. At its southern end, the lagoon also receives an important freshwater discharge from the Tamacuil River. In consequence, salinity varies between 0.5 in September and 33 in April (annual monthly mean: 13), with general mesohaline conditions prevailing. The local rainfall regime is characterized by a wet season from June to October, with annual averages greater than $120 \mathrm{~mm}$, and a dry season from November to May, with annual averages of less than $50 \mathrm{~mm}$ [9]. Phytoplankton, chlorophyll and primary production show two maximum peaks, one from March to May and another from August to October [10].

\subsection{Data Collection}

Data were collected during daylight hours at six sites within the lagoon, once a month during a one-year period (a total of 72 samples), in order to evaluate the seasonal patterns of fish distribution. A $30 \mathrm{~m}$ long and $1 \mathrm{~m}$ deep beach seine net, with $1 \mathrm{~cm}$ mesh size, was used in all sampling efforts. The net was pulled $50 \mathrm{~m}$ parallel to the shore and covering a sampling area of $1500 \mathrm{~m}^{2}$ in water up to $1 \mathrm{~m}$ deep.

The total fish number, the number of individuals per species and environmental data were recorded for each sample. The environmental variables measured during sampling included those with major seasonal incidence: temperature, salinity, depth, turbidity (Secchi disk depth) and monthly rainfall average in the area (average for 60 years).

\subsection{Statistical Analyses}

Canonical correspondence analysis (CCA) was applied to the overall fish data matrix (dependent set) and the environmental data matrix (independent set) in order to elucidate the relationships between biological assemblages of species and the environmental variables. This method evaluates and permits the visualization of the differential habitat preferences (niches) of taxa via an ordination diagram. CCA is an appropriate constrained ordination technique designed for the exploration of the corresponddence between physical factors and species composition, which is less susceptible than other ordination methods to nonlinearities, because it explicitly assumes nonlinear responses (i.e., Gaussian) of species along environmental gradients $[11,12]$. Rare species were down-weighted and ordination axes were rescaled in order to produce a biplot of the species data matrix constrained by the environmental ordination. Inter-set correlations of this analysis were used to determine the environmental variables that were most important in determining species abundance [12].

Simple correlation analyses (r) were used to measure the degree of association between fish number and environmental variables [13]. A cross-correlation was used between two time-series variables, rainfall and fish numbers, to determine whether one influences the other with a delayed effect (maximum number of lags considered $=$ 11).

Finally, one-way analysis of variance (ANOVA) was employed to check for differences in fish number between climatic seasons. Prior to the above analyses, abundance data were square-root transformed [14].

\section{Results}

\subsection{Overall Fish Composition}

In 72 samples, a total of 9108 individuals weighing $30,297 \mathrm{~g}$ were caught, corresponding to 30 families and 66 species of fish, most of them marine species, showing tropical and subtropical affinities. Only four were typical freshwater species: Oreochromis mossambicus (an introduced species), Fundulus grandis, Poecilia mexicana and Astyanax mexicanus (the latter three with $\mathrm{n}<12$ ).

The most-represented families with respect to species number and abundance were: Engraulidae, Atherinopsidae, Sciaenidae, Ariidae, Gerreidae and Clupeidae.

A simultaneous ordination of species and environmental matrices in CCA arranged the 66 fish species in terms of their abundance in the 72 samples collected during this study (Figure 1). The first two axes explained $72.82 \%$ of the cumulative constrained variance in the species-environment bi-plot (axis 1, 51.82\%; axis 2, $21.00 \%$ ). Also species-environment correlations were relatively high $(0.717$ and 0.628 , for the first and second axes, respectively). According to inter-set correlations, for the first axis, salinity $(0.521)$ and rainfall $(-0.426)$ were the most important environmental variables acting on the structure of the fish community. For the second axis were turbidity $(-0.431)$, depth $(-0.367)$ and rainfall (0.222). Moreover, inter-set correlations showed the relatively low importance of temperature in the structuring of 


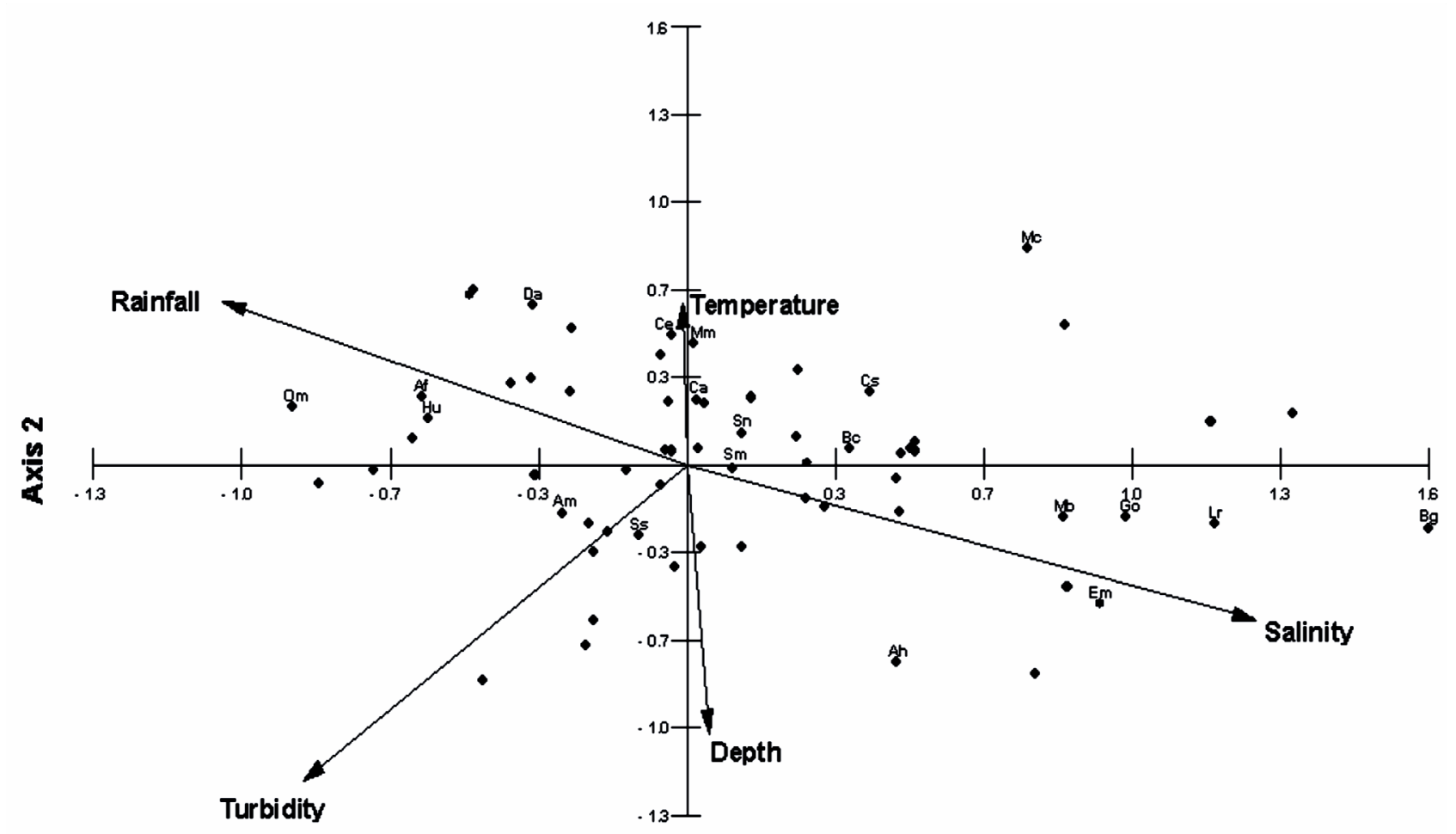

Ved or scaling: 1.73

Axis 1

Figure 1. Canonical correspondence analysis bi-plot of the overall species and environmental variable data matrices. Length and direction of arrows indicate the relative importance and direction of change of environmental variables. The habitat preferences of the 20 most abundant species $(n>40)$ are indicated by the genera and species names initials, including (in abundance order): Anchoa mitchilli (Am), Membras martinica (Mm), Bairdiella chrysoura (Bc), Cathorops aguadulce (Ca), Diapterus auratus (Da), Lagodon rhomboides (Lr), Brevoortia gunteri (Bg), Gobionellus oceanicus (Go), Anchoa hepsetus (Ah), Mugil curema (Mc), Ariopsis felis (Af), Eucinostomus melanopterus (Em), Menidia beryllina (Mb), Strongylura notata (Sn), Cetengraulis edentulus (Ce), Oreochromis mossambicus (Om), Syngnathus scovelli (Ss), Strongylura marina (Sm), Citharichthys spilopterus (Cs) and Hyporhamphus unifasciatus (Hu).

the fish community (axis $1,-0.004$; axis $2,0.220$ ).

These results reveal a main ordination gradient going from the first ordination quadrant (negative values on axis 1 and positive on axis 2) to the fourth quadrant (positive values on axis 1 and negative on axis 2), which is related to a rainfall-salinity gradient. Throughout this gradient are located the preferences of most species. Another major trend, nearly perpendicular to the first one, extends from the third ordination quadrant (negative values on both axes) to the second quadrant (positive values on both axes), which is related to a turbidity and depth gradient.

In this way, the species mainly influenced by freshwater conditions are observed in the left end of the rainfall-salinity gradient (O. mossambicus, Ariopsis felis, Hyporhamphus unifasciatus, Diapterus auratus, Anchoa mitchilli, Cetengraulis edentulus, Membras martinica and Cathorops aguadulce), whereas the right end contains species caught primarily when salinity was relatively high (Brevoortia gunteri, Lagodon rhomboides, Eucinostomus melanopterus, Gobionellus oceanicus, Me- nidia beryllina and Anchoa hepsetus). The area be- tween these two extremes included species also influ- enced by turbidity and depth (Citharichthys spilopterus, Bairdiella chrysoura, Mugil curema and A. mitchilli).

\subsection{Individual Effect of Each Environmental Variable}

According to the importance of environmental variables, it was evaluated la influence of each factor on the total fish number and the abundance of the most abundant species. In general, total fish number increased during the rainy season (July-October), but the correlation between local rainfall and total fish abundance, was not significant $(\mathrm{P}>0.4)$. However, seasonal fluctuations in total fish number were linked to preceding fluctuations (one month) in local rainfall (Figure 2(a)). Thus, the cross-correlation analysis showed that changes in monthly mean numbers were positively correlated $(r=0.792$, d.f. $=10, P=0.025)$, with changes in mean rainfall for the previous month (delayed effect). 

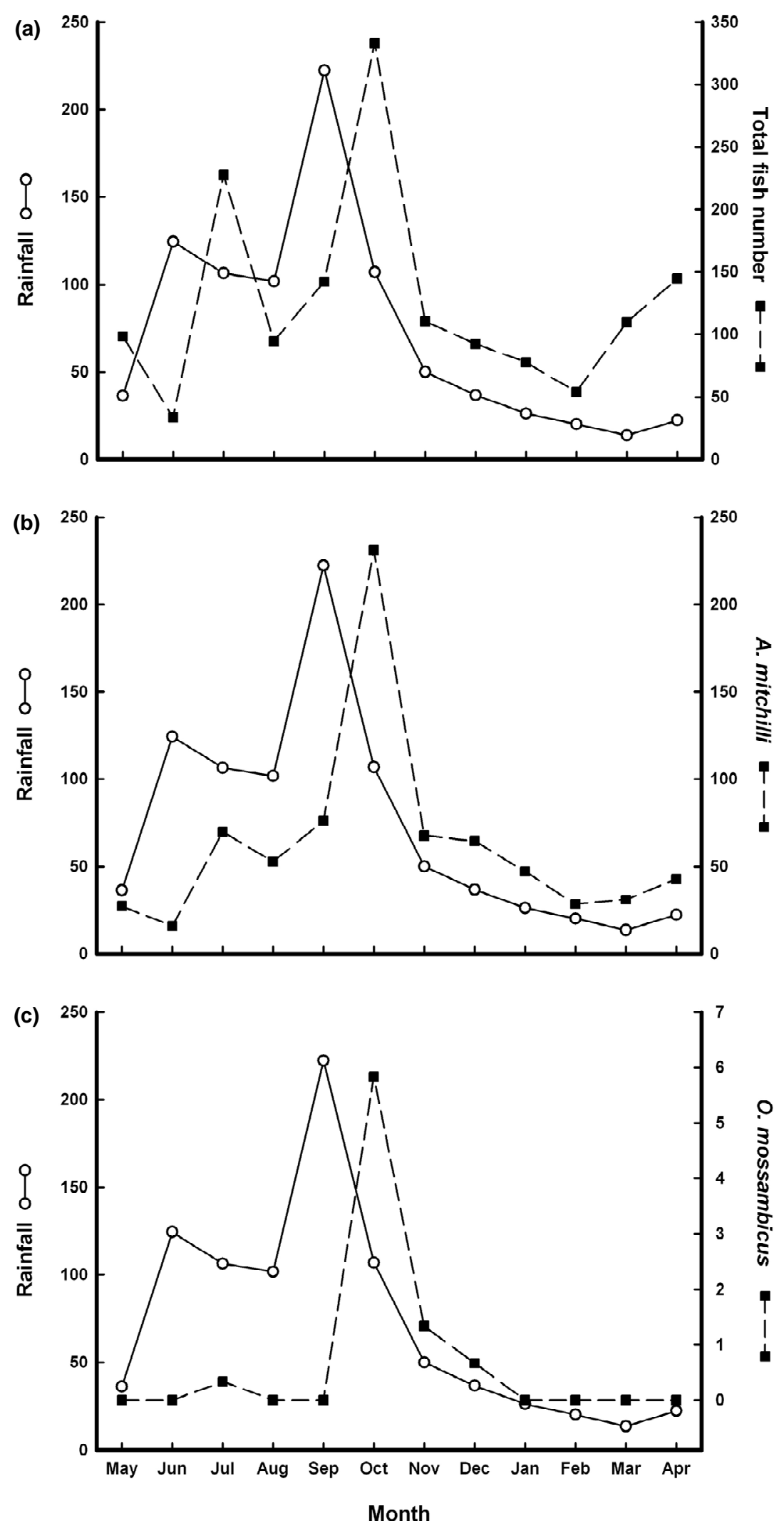

Figure 2. Relationship between monthly mean number and mean monthly local rainfall in cm in Pueblo Viejo lagoon. Total fish number (a), Anchoa mitchilli (b) and Oreochromis mossambicus (c). Note delayed effect of rainfall (one month) on the number of individuals captured. 
Similarly, although the abundance of A. mitchilli (the most abundant species), O. mossambicus and A. felis showed no significant direct correlation with rainfall (P's $>0.18$ ), seasonal fluctuations in the monthly means of these species were significantly correlated with preceding fluctuations (also by one month; Figure 2) in local rainfall (cross-correlations: $\mathrm{r}=0.844$, d.f. $=10, \mathrm{P}=0.019$ for A. mitchilli; $\mathrm{r}=0.780$, d.f. $=10, \mathrm{P}=0.027$ for $O$. mossambicus; $\mathrm{r}=0.726$, d.f. $=10, \mathrm{P}=0.037$ for $A$. felis $)$.

Other species exhibited a direct relationship with the local rainfall pattern. Thus, rainfall showed a significant positive correlation with $M$. martinica $(\mathrm{r}=0.255$, d.f. $=$ $70, \mathrm{P}=0.031$; Figure 3(a)), D. auratus $(\mathrm{r}=0.313$, d.f. $=$ $70, \mathrm{P}=0.008$; Figure $\mathbf{3 ( b )})$ and $H$. unifasciatus $(\mathrm{r}=$ 0.325 , d.f. $=70, \mathrm{P}=0.005$ ). Furthermore, analyses of variance found that the abundance of $D$. auratus, A. felis, $H$. unifasciatus and $C$. spilopterus were consistently higher during the rainy season $(\mathrm{F}$ 's $>4.04$; d.f. $=1 / 70, \mathrm{P}$ 's $>$ $0.05)$.

By contrast, there was a significant inverse correlation between rainfall and the abundance of $B$. gunteri $(\mathrm{r}=$ -0.261 , d.f. $=70, \mathrm{P}=0.027$; Figure 4(a)) and therefore,

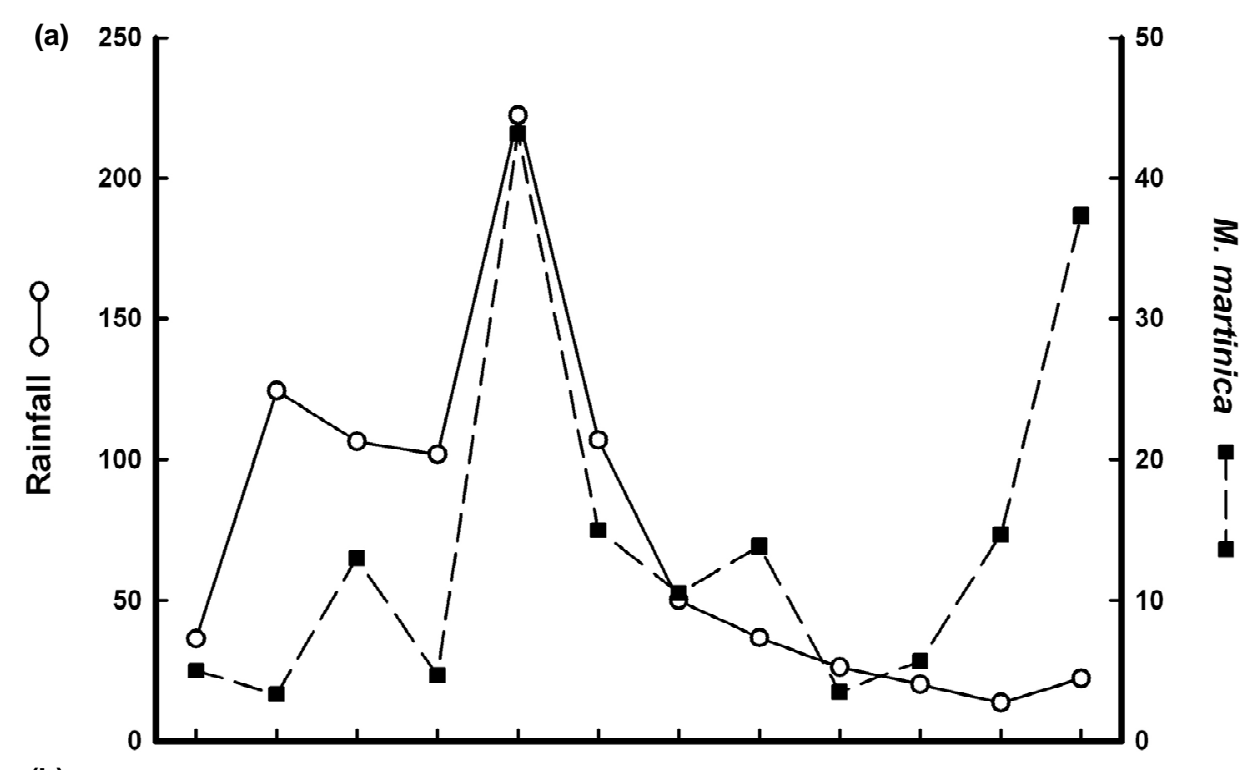

(b)

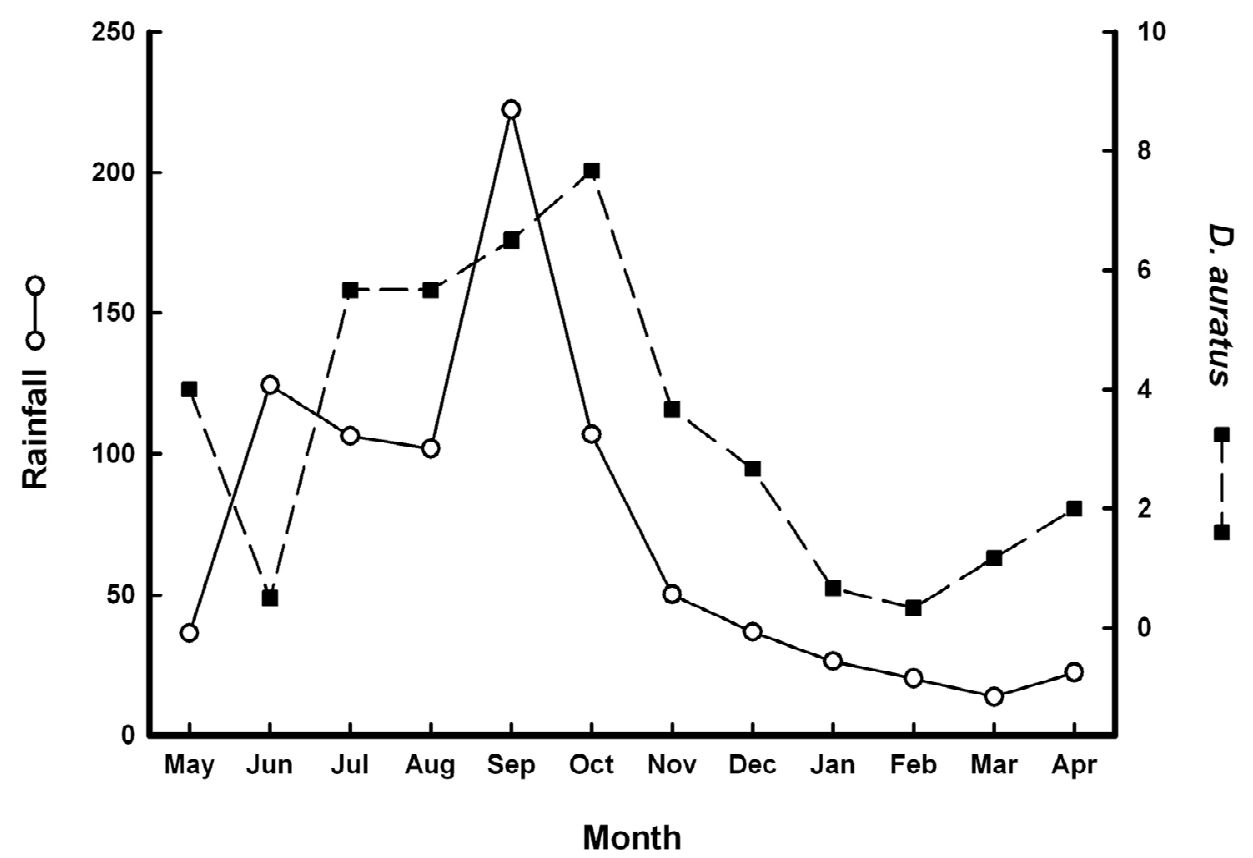

Figure 3. Direct relationship between monthly mean number and mean monthly local rainfall in cm in Pueblo Viejo lagoon. Membras martinica (a) and Diapterus auratus (b). 

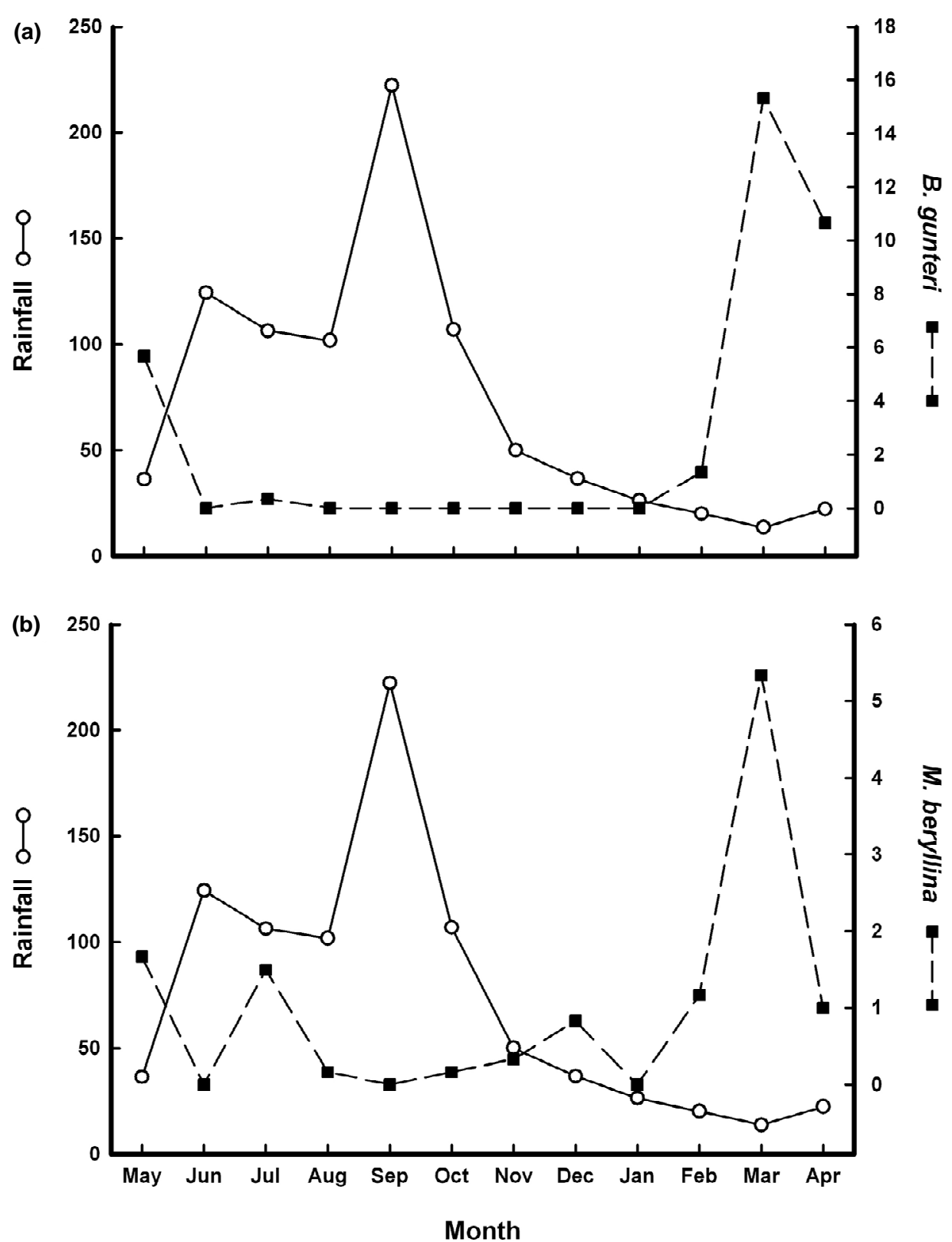

Figure 4. Inverse relationship between monthly mean number and mean monthly local rainfall in cm in Pueblo Viejo lagoon. Brevoortia gunteri (a) and Menidia beryllina (b).

the abundance of this species was significantly higher during dry season $(\mathrm{F}=4.74$; d.f. $=1 / 70, \mathrm{P}$ 's $=0.033)$. There was also a significant inverse correlation between rainfall and the abundance of $M$. beryllina $(\mathrm{r}=-0.246$, d.f. $=70, \mathrm{P}=0.048$; Figure 4(b)).

Environmental variables influenced by local rainfall pattern also show relationship with the species abundance. Salinity was positively correlated with the abundance of $B$. gunteri $(\mathrm{r}=0.361$, d.f. $=70, \mathrm{P}=0.002)$ and $A$. hepsetus $(\mathrm{r}=0.396$, d.f. $=70, \mathrm{P}<0.001)$, and inversely correlated with $D$. auratus $(\mathrm{r}=-0.266$, d.f. $=70, \mathrm{P}=$ $0.024)$. In addition, depth correlated significantly with $A$. mitchilli $(\mathrm{r}=0.264$, d.f. $=70, \mathrm{P}=0.025)$, B. chrysoura $(\mathrm{r}$ $=0.276$, d.f. $=70, \mathrm{P}=0.019)$, C. spilopterus $(\mathrm{r}=0.303$, d.f. $=70, \mathrm{P}=0.009)$ and $H$. unifasciatus $(\mathrm{r}=0.287$, d.f. $=$ $70, \mathrm{P}=0.015)$. Finally, turbidity only correlated significantly with $M$. curema $(\mathrm{r}=-0.263$, d.f. $=70, \mathrm{P}=0.026)$.

In this way, nine species showed some relationship with the local rainfall pattern, which accounted for $68.91 \%$ of the total number of fish collected. In addition, three other species showed some relationship to environmental variables influenced by the rainfall regime (salinity, depth and turbidity) and these accounted for $12.36 \%$ of the total fish number. 


\section{Discusion}

\subsection{Overall Fish Composition}

Most of the species recorded in the present study are of marine origin [15], despite the fact that the system exhibits a typically mesohaline condition and has restricted communication with the sea $[8,9]$. In this way, it is particular interesting to note the low occurrence of typical freshwater species.

The seasonal variation of fish species abundance in estuaries can be regulated, synergistically or individually, by fluctuations in environmental conditions [16-18].

In the present study, with respect to the ordination of CCA, the first two canonical axes explained $72.82 \%$ of the total constrained variance and showed relatively high correlations between species and environmental variables. From this analysis, the rainfall-salinity gradient was revealed to be the most important driving force in the seasonal variation of fish composition in the Pueblo Viejo lagoon. Likewise, salinity, depth and turbidity, related to seasonal variation in rainfall and freshwater inflow, also play an important role in affecting the abundance of species. Due to the large seasonal fluctuations in these factors, the relative composition of the fish fauna of the lagoon varies greatly throughout the year.

Strong seasonal changes in the abundance of fish species are relatively common and some studies on fish communities in tropical and subtropical estuaries have related these changes with local rainfall patterns $[9,18]$ and freshwater discharges [19-21]. Moreover, in many estuaries, abiotic factors such as turbidity and salinity have a significant effect on fish distribution, and the levels and ranges of these factors also can be largely determined by the seasonal rainfall patterns [3,5,6,22].

Although temperature is often cited as a major factor affecting seasonal abundance of fish species in estuaries $[1,16,23]$, in Pueblo Viejo lagoon, the negligible influence of this factor over fish community structure is probably related to the warm conditions of this system and its predominately tropical ichthyofauna. Similarly, in other tropical and subtropical estuaries, temperature effects have been considered minimal within normal seasonal ranges [24,25]. Indeed, in tropical estuaries with moderate seasonal temperature and solar radiation, temporal changes in rainfall seem to play an important role [9].

\subsection{Individual Effect of Each Environmental Variable}

In relation to the influence of each environmental variable, in Pueblo Viejo Lagoon, the peak of total fish number in October was related to rainy season and in general, seasonal fluctuations in total fish abundance were linked to preceding rain fluctuations. Similar pattern was exhibited by the abundance of $A$. mitchilli (the most abundant species), O. mossambicus and A. felis (Figure 2). Thus, cross correlation indicated that the higher and lower values in local rainfall have a significant delayed effect (by one month) on greater and smaller catches in fish number. In addition, the rainfall showed a significant positive correlation with $D$. auratus and M. martinica, showing a direct influence on the abundance of these species (Figure 3). Also, the abundance of $D$. auratus, A. felis, $H$. unifasciatus and C. spilopterus were significantly higher during the rainy season (June to October).

The association between the number of captured individuals and the rainfall regime seems to be related to lagoon productivity. Rain increases river discharge and riverine freshwater runoff, and brings an increased amount of allochthonous organic matter and dissolved nutrients into the system [26]. In many littoral systems, the additional nutrients facilitate grazer pathway (phytoplankton route) and the organic matter promotes detritus pathway (microbivore route) [27]. Both pathways enhance food availability during the wet season, which may contribute to an increase in fish abundance. The time lag between the grazer and detritus pathway stimulations and the increase in trophic resources on which fish feed may account for the delayed rainfall effect on fish abundance.

Indeed, feeding studies in Pueblo Viejo have shown that A. mitchilli, A. felis, D. auratus, M. martinica and C. spilopterus feed more intensively during the rainy season (July to October), being the detritus an important food resource in their diet in this period [28-30]. As noted, seasonal fluctuations in species abundance can be closely associated with seasonal food availability [31].

Conversely, species that feed on plankton such as $B$. gunteri and $M$. beryllina show an inverse correlation with rainfall. Although, the high occurrence of these species during March (dry season) has been related to trophic response associated to pulses of plankton in Pueblo Viejo lagoon [10], it was evident that these species are infrequent at months with mean rainfall greater to $50 \mathrm{~cm}$ (Figure 4).

Finally, other environmental variables (also influenced by rainfall regime) showed a relationship with three more species. Salinity and depth correlated positively with $A$. hepsetus and $B$. chrysoura (respectively), whereas turbidity correlated inversely with $M$. curema. Thus, the 12 species mentioned above showed some relationship with local rainfall, which accounted for $81.27 \%$ of the total number of fish collected.

Although it is difficult for many species to separate the relative importance of physiological tolerances and biological functions such as trophic responses, the results suggest that rainfall, and probably its associated influ- 
ence on availability of food, is a primary factor governing seasonal variation in species abundance of Pueblo Viejo lagoon.

\section{REFERENCES}

[1] T. D. Harrison and A. K. Whitfield, "Temperature and Salinity as Primary Determinants Influencing the Biogeography of Fishes in South African Estuaries," Estuarine, Coastal and Shelf Science, Vol. 66, No. 1-2, 2006, pp. 335-345. doi:10.1016/j.ecss.2005.09.010

[2] M. Castillo-Rivera, R. Zárate-Hernández, S. Ortiz-Burgos and J. Zavala-Hurtado, "Diel and Seasonal Variability in the Fish Community Structure of a Mud Bottom Estuarine Habitat in the Gulf of Mexico," Marine Ecology, Vol. 31, No. 4, 2010, pp. 633-642. doi:10.1111/j.1439-0485.2010.00394.x

[3] S. J. M. Blaber, D. T. Brewer and J. P. Salini, "Fish Communities and the Nursery Role of the Shallow Inshore Waters of a Tropical Bay in the Gulf of Carpentaria, Australia," Estuarine, Coastal and Shelf Science, Vol. 40, No. 2, 1995, pp. 177-193. doi:10.1016/S0272-7714(05)80004-6

[4] S. P. Griffiths, "Factors Influencing Fish Composition in an Australian Intermittently Open Estuary. Is Stability Salinity-Dependent?" Estuarine, Coastal and Shelf Science, Vol. 52, No. 6, 2001, pp. 739-751. doi:10.1006/ecss.2000.0756

[5] E. J. Martino and K. W. Able, "Fish assemblages across the marine to low salinity transition zone of a temperate estuary," Estuarine, Coastal and Shelf Science, Vol. 56, No. 5-6, 2003, pp. 969-987. doi:10.1016/S0272-7714(02)00305-0

[6] M. Barletta, A. Barletta-Bergan, U. Saint-Paul and G. Hubold, "The Role of Salinity in Structuring the Fish Assemblages in a Tropical Estuary," Journal of Fish Biology, Vol. 66, No. 1, 2005, pp. 45-72. doi:10.1111/j.0022-1112.2005.00582.x

[7] P. B. Moyle and J. J. Cech, "Fishes: An Introduction to Ichthyology," 5th Edition, Prentice-Hall, New Jersey, 2004.

[8] R. Zárate-Hernández, M. Castillo-Rivera, L. SanvicenteAñorve and S. Ortiz-Burgos, "Spatial, Diel, and Seasonal Changes in the Fish Community Structure of a Mexican Tropical Estuary," Ciencias Marinas, Vol. 38, No. 4, 2012, pp. 665-676. doi:10.7773/cm.v38i4.2018

[9] M. Castillo-Rivera, J. A. Zavala-Hurtado and R. ZárateHernández, "Exploration of Spatial and Temporal Patterns of Fish Diversity and Composition in a Tropical Estuarine System of Mexico," Review in Fish Biology and Fisheries, Vol. 12, No. 2-3, 2002, pp. 167-177. doi:10.1023/A:1025051027676

[10] F. Contreras, "Producción Primaria Fitoplanctónica en Lagunas Costeras," Revista de Investigaciones Marinas, Vol. 16, No. 1, 1995, pp. 11-21.

[11] C. J. F. ter Braak and P. F. M. Verdonschot, "Canonical Correspondence Analysis and Related Multivariate Methods in Aquatic Ecology," Aquatic Sciences, Vol. 57,
No. 3, 1995, pp. 255-289. doi:10.1007/BF00877430

[12] K. McGarigal, S. Cushman and S. Stafford, "Multivariate Statistics for Wildlife and Ecology Research," SpringerVerlag, New York, 2000. doi:10.1007/978-1-4612-1288-1

[13] J. H. Zar, "Biostatistical Analysis," 5th Edition, PrenticeHall Pearson, New Jersey, 2010.

[14] N. J. Gotelli and A. M. Ellison, "A Primer of Ecological Statistics," Sinauer Associates, Massachusetts, 2004.

[15] J. S. Nelson, "Fishes of the World," 4th Edition, John Wiley, New York, 2006.

[16] D. A. Methven, R. L. Haedrich and G. A. Rose, "The Fish Assemblage of a Newfoundland Estuary: Diel, Monthly, and Annual Variation," Estuarine, Coastal and Shelf Science, Vol. 52, No. 6, 2001, pp. 669-687. doi:10.1006/ecss.2001.0768

[17] A. M. Pessanha and F. G. Araújo, "Spatial, Temporal and Diel Variations of Fish Assemblages at Two Sandy Beaches in the Sepetiba Bay, Rio de Janeiro, Brazil," Estuarine, Coastal and Shelf Science, Vol. 57, No. 5-6, 2003, pp. 817-828. doi:10.1016/S0272-7714(02)00411-0

[18] J. O. Meynecke, S. Y. Lee, N. C. Duke and J. Warnken, "Effect of Rainfall as a Component of Climate Change on Estuarine Fish Production in Queensland, Australia," Estuarine, Coastal and Shelf Science, Vol. 69, No. 3-4, 2006, pp. 491-504. doi:10.1016/j.ecss.2006.05.011

[19] W. J. Kimmerer, "Effects of Freshwater Flow on Abundance of Estuarine Organisms: Physical Effects or Trophic Linkages?" Marine Ecology Progress Series, Vol. 243, 2002, pp. 39-55. doi:10.3354/meps243039

[20] T.-S. Tsou and R. E. Matheson, "Seasonal Changes in the Nekton Community of the Suwanee River Estuary and Potential Impacts of the Freshwater Withdrawal," Estuaries, Vol. 25, No. 6, 2002, pp. 1372-1381. doi:10.1007/BF02692231

[21] G. C. Young and I. C. Potter, "Influence of Exceptionally High Salinities, Marked Variations in Freshwater Discharge and Opening of Eestuary Mouth on the Characteristics of the Ichthyofauna of a Normally-Closed Estuary," Estuarine, Coastal and Shelf Science, Vol. 55, No. 2, 2002, pp. 223-246. doi:10.1006/ecss.2001.0899

[22] R. Thiel, A. Sepúlveda, R. Kafemann and W. Nellen, "Environmental Factors as Forces Structuring the Fish Community of the Elbe Estuary," Journal of Fish Biology, Vol. 46, No. 1, 1995, pp. 47-69. doi:10.1111/j.1095-8649.1995.tb05946.x

[23] S. M. Hagan and K. W. Able, "Seasonal Changes of the Pelagic Fish Assemblage in a Temperate Estuary," Estuarine, Coastal and Shelf Science, Vol. 56, No. 1, 2003, pp. 15-29. doi:10.1016/S0272-7714(02)00116-6

[24] P. D. Vorwerk, A. K. Whitfield, P. D. Cowley and A. W. Paterson, "The Influence of Selected Environmental Variables on Fish Assemblage Structure in a Range of Southeast African Estuaries," Environmental Biology of Fishes, Vol. 66, No. 3, 2003, pp. 237-247. doi:10.1023/A:1023922521835

[25] N. C. James, A. K. Whitfield and P. D. Cowley, "LongTerm Stability of the Fish Assemblages in a Warm- 
Temperate South African Estuary," Estuarine, Coastal and Shelf Science, Vol. 76, No. 4, 2008, pp. 723-738. doi:10.1016/j.ecss.2007.07.036

[26] M. Castillo-Rivera M., M. Montiel, L. SanvicenteAñorve and R. Zárate-Hernández, "Spatial, Seasonal and Diel Distribution Patterns of Two Species of Mojarras (Pisces: Gerreidae) in a Mexican Tropical Coastal Lagoon," Journal of Applied Ichthyology, Vol. 21, No. 6, 2005, pp. 498-503. doi:10.1111/j.1439-0426.2005.00661.x

[27] R. S. K. Barnes and R. N. Hughes, "An Introduction to Marine Ecology," 3rd Edition, Blackwell Publishing, Oxford, 1999. doi:10.1002/9781444313284

[28] M. Castillo-Rivera, G. Moreno and R. Iniestra, "Spatial, Seasonal, and Diel Variation in Abundance of the Bay Anchovy, Anchoa mitchilli (Teleostei: Engraulidae), in a
Tropical Coastal Lagoon of Mexico," The Southwestern Naturalist, Vol. 39, No. 3, 1994, pp. 263-268. doi: $10.2307 / 3671591$

[29] M. Castillo-Rivera and R. Zárate, "Patrones EspacioTemporales de la Abundancia de Peces en la Laguna de Pueblo Viejo, Veracruz," Hidrobiológica, Vol. 11, No. 1, 2001, pp. 75-84.

[30] M. Castillo-Rivera, "Biología Trófica de Peces Costeros. Estuarios del Golfo de México Occidental," Editorial Académica Española, LAP LAMBERT Academic Publishing GMBH \& Co. KG, Saarbrücken, 2011.

[31] T. Madurell, J. E. Cartes and M. Labropoulou, "Changes in the Structure of Fish Assemblages in a Bathyal Site of the Ionian Sea (Eastern Mediterranean)," Fisheries Research, Vol. 66, No. 2-3, 2004, pp. 245-260. doi:10.1016/S0165-7836(03)00205-4 